\title{
Classification of Muscarinic Responses in Hippocampus in Terms of Receptor Subtypes and Second-Messenger Systems: Electrophysiological Studies in vitro
}

\author{
P. Dutar a and R. A. Nicoll \\ Departments of Pharmacology and Physiology, University of California, San Francisco, California 94143
}

\begin{abstract}
The hippocampal slice preparation was used to classify cholinergic effects in terms of muscarinic receptor subtypes $\left(M_{1}\right.$ or $M_{2}$ ) and biochemical effector systems linked to these effects in $\mathbf{C A}_{1}$ pyramidal cells. Based on the action of the $\mathbf{M}_{1}$ antagonist pirenzepine and the $M_{2}$ antagonist gallamine, the muscarinic-induced membrane depolarization and blockade of the afterhyperpolarization appear to result from activation of an $M_{1}$ receptor, while the cholinergic depression of the EPSP and the blockade of a potassium current termed the $M$-current appears to involve the activation of an $\mathrm{M}_{2}$ receptor. All of the muscarinic actions could be observed in pertussis toxin-treated hippocampi, suggesting that a pertussis toxinsensitive G-protein is not involved in these actions. Cholinergic agents that are weak agonists of phosphoinositide (PI) turnover are fully effective in all of the muscarinic actions except the blockade of the M-current, on which they had little agonist activity and actually blocked the action of full agonists. These results strongly suggest that the blockade of the M-current may involve stimulation of PI turnover. In addition, we show that the blockade of the M-current is mimicked by intracellular application of inositol trisphosphate. Our results do not show any obvious relationship between the muscarinic receptor subtypes and the biochemical effector systems.
\end{abstract}

Muscarinic receptors have been shown to evoke a wide variety of responses in different tissues, suggesting that a number of muscarinic receptor subtypes might exist. This conclusion is strongly supported by recent results with molecular cloning, which have identified at least 4 functional muscarinic receptor clones (Bonner et al., 1987). Pharmacological studies have been less successful at defining muscarinic receptor subtypes. However, based on the relative sensitivity of muscarinic responses to pirenzepine, receptors have been subdivided into $M_{1}$ and $M_{2}$ types, the $M_{1}$ subtype being approximately 100 -fold more sensitive to the antagonist (Hammer et al., 1980). Moreover, gallamine has been found to bind with high affinity to the $\mathbf{M}_{2}$ receptor subtypes in rat brain (Burke, 1986). Electrophysiolog-

\footnotetext{
Received Dec. 3, 1987; revised Mar. 21, 1988; accepted Mar. 25, 1988.

This work was supported by NIH Grants MH38256, MH0437 (RSDA), and NS24205 to R.A.N. P.D. was supported by the Fogarty International Center of NIH (TW03789) and by the IPSEN Foundation.

Correspondence should be addressed to R. A. Nicoll, Department of Pharmacology, University of California, School of Medicine, San Francisco, CA 94143 0450 .

a Present address: Laboratoire de Neurophysiologie Pharmacologique, INSERM U 161, 2 rue d'Alésia, 75014 Paris, France.

Copyright (C) 1988 Society for Neuroscience $0270-6474 / 88 / 114214-11 \$ 02.00 / 0$
}

ical studies in the CNS on the classification of muscarinic responses have focused primarily on the $\mathrm{M}_{1} / \mathrm{M}_{2}$ classification. $\mathrm{M}_{1}$ receptors appear to be involved in the depolarization of pyramidal neurons of cortex (McCormick and Prince, 1985) and hippocampus (Muller and Misgeld, 1986). $M_{2}$ receptors appear to be involved in the activation of cortical interneurons (McCormick and Prince, 1985) and locus coeruleus neurons (Egan and North, 1985), and also in hyperpolarizing responses induced by cholinergic agonists (Egan and North, 1986; McCormick and Prince, 1986). The muscarinic blockade of the afterhyperpolarization (AHP) that follows a series of action potentials may involve an $\mathrm{M}_{2}$ receptor (Muller and Misgeld, 1986; Constanti and Sim, 1987b), although some evidence implicates an $\mathbf{M}_{1}$ reccptor (Colc and Nicoll, 1984).

Another approach that has been used to classify muscarinic responses is to determine the mechanism involved in the coupling of the receptor to the response. For instance, pertussis toxin (PTX) has been used to demonstrate that some muscarinic responses require a PTX-sensitive GTP-binding protein (Breitwieser and Szabo, 1985; Pfaffinger et al., 1985; Dascal et al., 1986). In addition, biochemical studies on phosphoinositide (PI) turnover have revealed that in the brain muscarinic agonists can be divided into 2 groups, those that are full agonists at stimulating PI turnover and those that are weak partial agonists (Fisher et al., 1983, 1984; Jacobson et al., 1985). However, studies attempting to demonstrate the involvement of $M_{1}$ or $M_{2}$ receptor subtypes in PI turnover remain controversial (see Eglen and Whiting, 1986).

In the present study we have used a variety of approaches to characterize the various muscarinic responses that can be recorded from $\mathrm{CA}_{1}$ hippocampal pyramidal cells.

\section{Materials and Methods}

The methods used in this paper are similar to those used in other studies from this laboratory (Nicoll and Alger, 1981). Rat hippocampal slices, $400 \mu \mathrm{m}$ thick, were cut and placed in a holding chamber for at least 1 $\mathrm{hr}$. A single slice was then transferred to the recording chamber and held between 2 nylon nets, submerged beneath a continuously superfusing medium that had been pregassed with $95 \% \mathrm{O}_{2}$ and $5 \% \mathrm{CO}_{2}$. The composition of the medium was (mM): $\mathrm{NaCl}, 119 ; \mathrm{KCl}, 2.5 ; \mathrm{MgSO}_{4}$, $1.3 ; \mathrm{CaCl}_{2}, 2.5 ; \mathrm{NaH}_{2} \mathrm{PO}_{4}, 1.0 ; \mathrm{NaHCO}_{3}, 26.2 ;$ glucose, 11 . The temperature of the medium was maintained between 29 and $31^{\circ} \mathrm{C}$.

Drugs applied by addition to the superfusion medium included 5-HT; the cholinergic agonists carbachol, oxotremorine, pilocarpine, arecoline (all from Sigma), oxotremorine-M (gift from Bayer); the cholinergic antagonists gallamine, atropine (Sigma), pirenzepine (gift from Boehringer Ingelheim); the phorbol esters phorbol 12,13 dibutyrate (PDBu), phorbol 12,13 diacetate (PDA) (Sigma), and baclofen (Ciba-Geigy). Drugs applied intracellularly by diffusion from the recording electrode included D-myoinositol 1,3,5-trisphosphate $\left(\mathrm{IP}_{3}\right)$ and calcium chelators ethylene- 
A

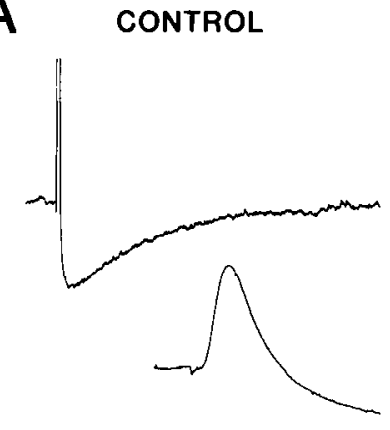

B

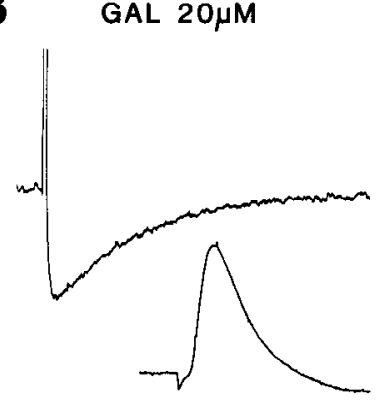

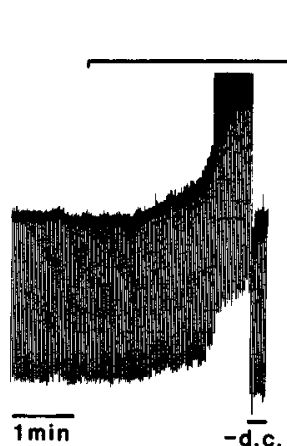

CARB $1 \mu \mathrm{M}$
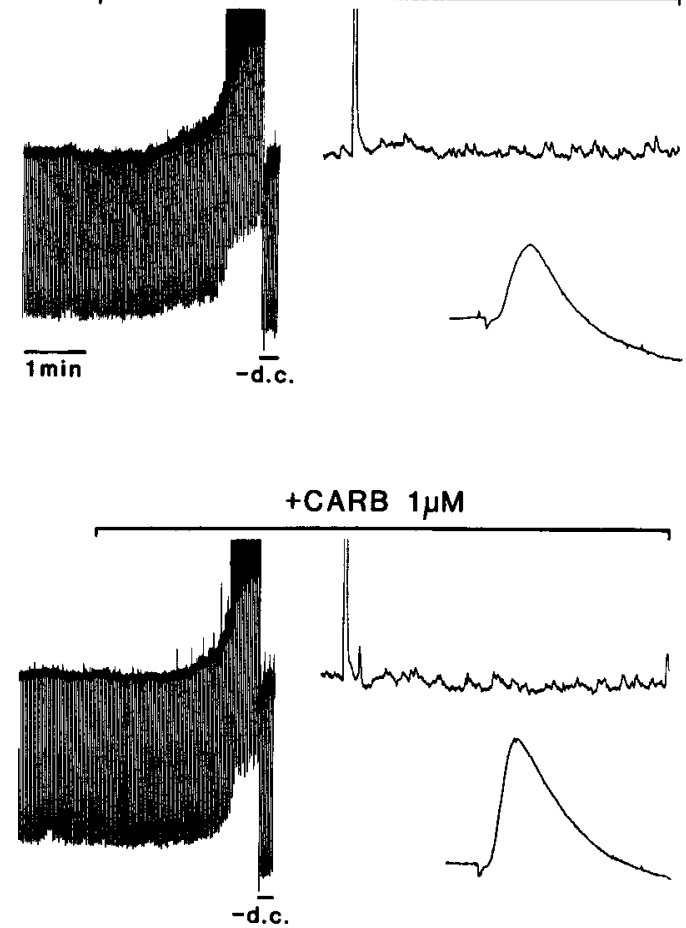

WASH
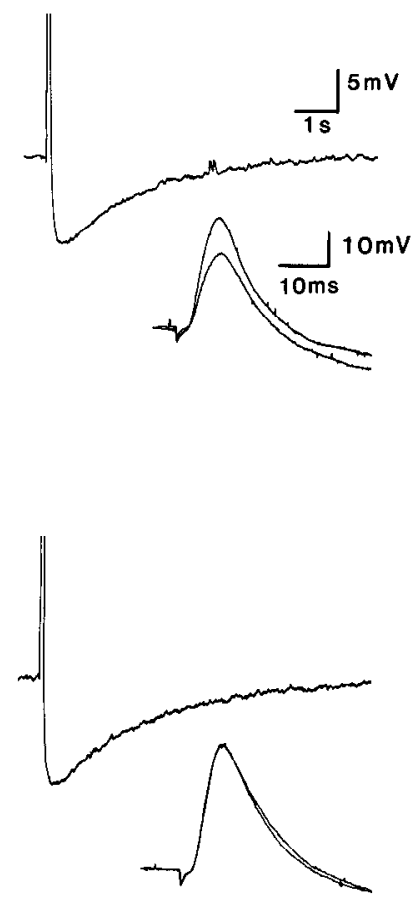

Figure 1. Antagonism of carbachol responses by gallamine. A, Chart recorder trace at left shows the AHP in response to a brief (60 msec) depolarizing current pulse at a fast chart speed and, below, the EPSP induced by stimulation of stratum radiatum. The chart speed is then reduced and constant current hyperpolarizing pulses are applied at $0.3 \mathrm{~Hz}$. Carbachol $(\operatorname{Carb} 1 \mu \mathrm{M})$ applied by superfusion in the bath during the time indicated by the $b a r$ induces a strong depolarization associated with an increase in input resistance [as shown by repolarizing the membrane potential to the control value $(-d . c$. $)$ ], blockade of the AHP, and depression of the EPSP. These effects recover after washing carbachol from the bath. The EPSP recorded in carbachol is superimposed on the trace recorded after washing. $B$, Gallamine is applied for 10 min before starting carbachol application. It failed to antagonize the depolarization and the blockade of the AHP. In contrast, the depression of the EPSP is antagonized. Membrane potential, $66 \mathrm{mV}$. The voltage and time calibrations in $A$ also apply to $B$.

glycol-bis ( $\beta$-aminoethylether) $N, N, N^{1}, N^{1}$-tetraacetic acid (EGTA) and (1,2-bis(o)-aminophenoxy) ethane- $N, N, N^{1}, N^{1}$-tetraacetic acid (BAPTA) (all from Sigma).

Conventional intracellular recordings from $\mathrm{CA}_{1}$ pyramidal cells were obtained using glass micropipettes, filled with $2 \mathrm{M}$ potassium methylsulfate and having resistances of 80-150 M . Excitatory and inhibitory postsynaptic potentials (EPSP and IPSP) were induced using bipolar stimulating electrodes positioned in the stratum radiatum to activate Schaffer collateral/commissural fibers. When recording EPSPs, the cell was hyperpolarized to -75 to $-85 \mathrm{mV}$ to prevent contamination of EPSPs with action potentials. These synaptic events were stored on a Nicolet 4094 digital oscilloscope and plotted on a Hewlett-Packard $7470 \mathrm{~A}$ digital plotter. To record the M-current, a single-electrode voltage-clamp (Axoclamp 2, Axon Instruments) was used. Electrodes were filled with $3 \mathrm{M}$ potassium chloride (resistance, $25-70 \mathrm{M} \Omega$ ), and the tips were coated with M-coat D (Measurements Group) to reduce electrode capacitance. These experiments were performed with TTX (CalBiochem) in the bath to block the generation of spontaneous IPSP currents. The headstage voltage was continuously monitored during the experiments, and the switching frequency was between 3 and $5 \mathrm{kHz}$, depending on the characteristics of the electrode employed.

In PTX (List Biological Laboratories) experiments, PTX was injected into the cerebral ventricle in 14 rats (1.5 $\mu \mathrm{g}$ in 8 and $2.5 \mu \mathrm{g}$ in 6) using a stereotaxic approach (Andrade et al., 1986). Hippocampal slices from these rats were recorded $3 \mathrm{~d}$ after the injection.

\section{Results}

We have studied 4 classes of cholinergic responses in hippocampal cells. (1) The long-duration depolarization observed with low concentrations of agonist, which is associated with actionpotential discharge and an increase in input resistance. This effect of cholinergic agonists is known to be due to a decrease in a potassium conductance (Benardo and Prince, 1982; Madison ct al., 1987). (2) The blockade of AHP that follows a series of action potentials and is due to an increase in a calciumdependent potassium conductance (Benardo and Prince, 1982; Cole and Nicoll, 1984). (3) The blockade of a voltage- and timedependent potassium current, called the M-current, originally described in bullfrog sympathetic ganglion cells (Brown and Adams, 1980) and more recently in rat hippocampus (Halliwell and Adams, 1982). (4) Finally, the depression of synaptic events triggered by electrical stimulation of afferents to the $\mathrm{CA}_{1}$ pyramidal cells (Shaffer collaterals). These synaptic events are composed of an EPSP followed by an IPSP. Cholinergic agonists, acting at a presynaptic level, are able to reduce the amplitude of the EPSP (presynaptic inhibition; Hounsgaard, 1978).

Classification of the muscarinic responses in terms of $M_{\text {, }}$ and $M_{2}$ receptor subtypes

Most of the cholinergic responses were elicited by bath application of carbachol, a cholinergic agonist that is not destroyed by acetylcholinesterase. Therefore, it is possible to obtain reproducible pharmacological responses, constant in intensity and duration. Carbachol at a low concentration $(1 \mu \mathrm{M})$ was able to depolarize the membrane, block the AHP, and depress the EPSP of every neuron tested $(n=16)$. However, the full blockade of the M-current required 10-20 times the concentration of agonist. We first examined the action of pirenzepine on the mus- 

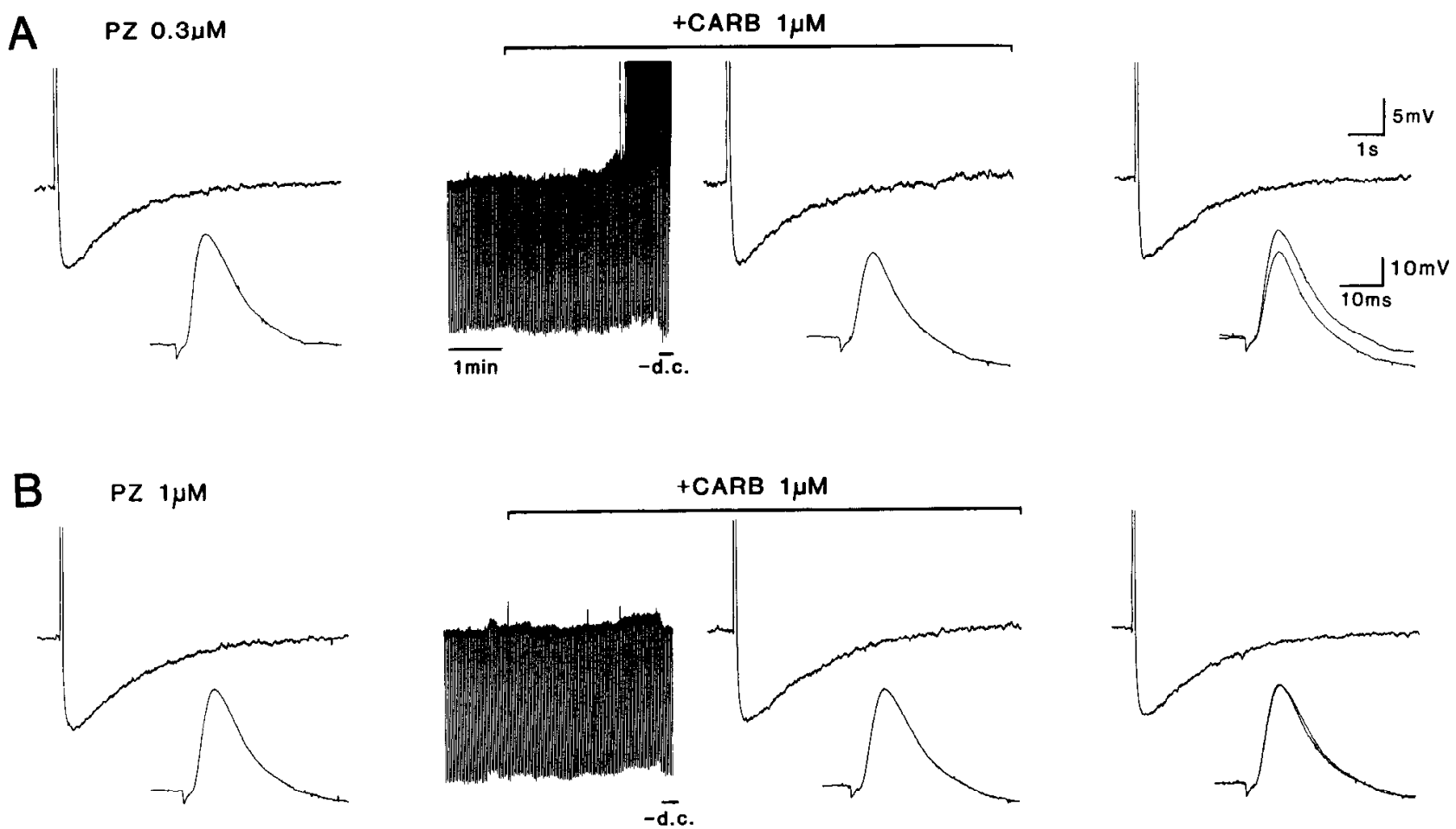

Figure 2. Antagonism by pirenzepine of carbachol responses. Same neuron and recording as in Figure 1. A, After washing out the gallamine (Fig. 1) for $20 \mathrm{~min}$, pirenzepine $(P Z)$ is applied at $0.3 \mu \mathrm{M}$ for $10 \mathrm{~min}$ before carbachol application. PZ strongly antagonizes the depolarization and the blockade of the AHP but fails to antagonize the depression of the EPSP. $B$, At $1 \mu \mathrm{M}$, PZ antagonizes all the cholinergic effects. Membrane potential, $-66 \mathrm{mV}$. Voltage and time calibrations in $A$ also apply to $B$.

carinic responses. The depolarization, blockade of the AHP, and depression of the EPSP were all antagonized to a similar extent by pirenzepine at $1 \mu \mathrm{M}$ (Fig. 2, Table 1). The depression of the EPSP was less sensitive to pirenzepine in some cells, as shown in Figure 2 for $0.3 \mu \mathrm{M}$ pirenzepine. The M-current was also less sensitive, but this could be due to the higher concentration of carbachol needed for this response (Fig. 3).

Thus, we were unable to clearly differentiate the various responses with pirenzepine. However, gallamine, an $\mathrm{M}_{2}$ antagonist (see Potter et al., 1984), did permit differentiation of the effects. Gallamine $(20 \mu \mathrm{M})$ had a very weak effect in antagonizing carbachol-induced depolarization $(n=6)$ and blockade of the AHP $(n=11)$; (see Table 1 and Fig. 1). In contrast, at this concentration, gallamine was able to produce a strong antagonism of the depression of the EPSP (Table 1, Fig. 1). Likewise, a near- total antagonism of the depression of $I_{\mathrm{M}}$ was observed in 12 out of 13 cells (Fig. 3, Table 1). Finally, atropine $(1 \mu \mathrm{M})$ a nonselective antagonist, was able to produce a very strong and longduration antagonism of the 4 effects $(n=4)$.

The results using gallamine suggest that an $\mathbf{M}_{2}$ receptor could mediate the depression of EPSP and blockade of $I_{M}$. In contrast, the depolarization and the blockade of the AHP, insensitive to gallamine and blocked by $0.3 \mu \mathrm{M}$ of $\mathrm{PZ}$, are probably mediated by $M_{1}$ receptors.

\section{Is a G-protein involved in the muscarinic action in the hippocampus?}

Various muscarinic effects are linked to the activation of a G-protein in different tissues. To test the possibility that a $\mathrm{G}$-protein may mediate the muscarinic responses in the hip-

\begin{tabular}{llllll}
\hline Table 1. Comparison of muscarinic antagonists on carbachol-induced effects & \\
Effect & Gal $(20 \mu \mathrm{M})$ & $\mathrm{PZ}(0.1 \mu \mathrm{M})$ & $\mathrm{PZ}(0.3 \mu \mathrm{M})$ & $\mathrm{PZ}(1 \mu \mathrm{M})$ & Atrop $(1 \mu \mathrm{M})$ \\
\hline Depolarization & $13( \pm 7)$ & $19( \pm 15)$ & $64( \pm 20)$ & $88( \pm 7)$ & 100 \\
& $n=6$ & $n=4$ & $n=6$ & $n=5$ & $n=3$ \\
Blockade of AHP & $14( \pm 16)$ & $31( \pm 22)$ & $78( \pm 14)$ & $93( \pm 15)$ & 100 \\
& $n=11$ & $n=5$ & $n=7$ & $n=5$ & $n=4$ \\
Depression of EPSP & $70( \pm 26)$ & $20( \pm 14)$ & $53( \pm 27)$ & $85( \pm 18)$ & $91( \pm 12)$ \\
& $n=12$ & $n=5$ & $n=8$ & $n=7$ & $n=3$ \\
Blockade of M-current & $75( \pm 26)$ & - & $33( \pm 18)$ & $72( \pm 25)$ & 100 \\
& $n=12$ & & $n=9$ & $n=3$ & $n=1$
\end{tabular}

Data are expressed as the mean percentage of antagonism of the cholinergic response ( \pm SD). The concentration of carbachol used to examine depolarization, blockade of the AHP, and depression of the EPSP was $1 \mu \mathrm{M}$. The concentration used to block the M-current was $20 \mu \mathrm{M} . n=$ number of neurons tested. Gal, gallamine; PZ, pirenzepine; Atrop, atropine. 


\section{CONTROL}

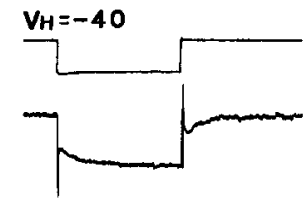

GAL $20 \mu \mathrm{M}$

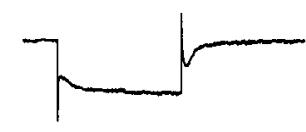

CONTROL

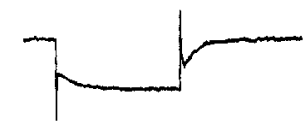

$\mathrm{PZ} 0.3 \mu \mathrm{M}$

\section{CARB $20 \mu \mathrm{M}$}
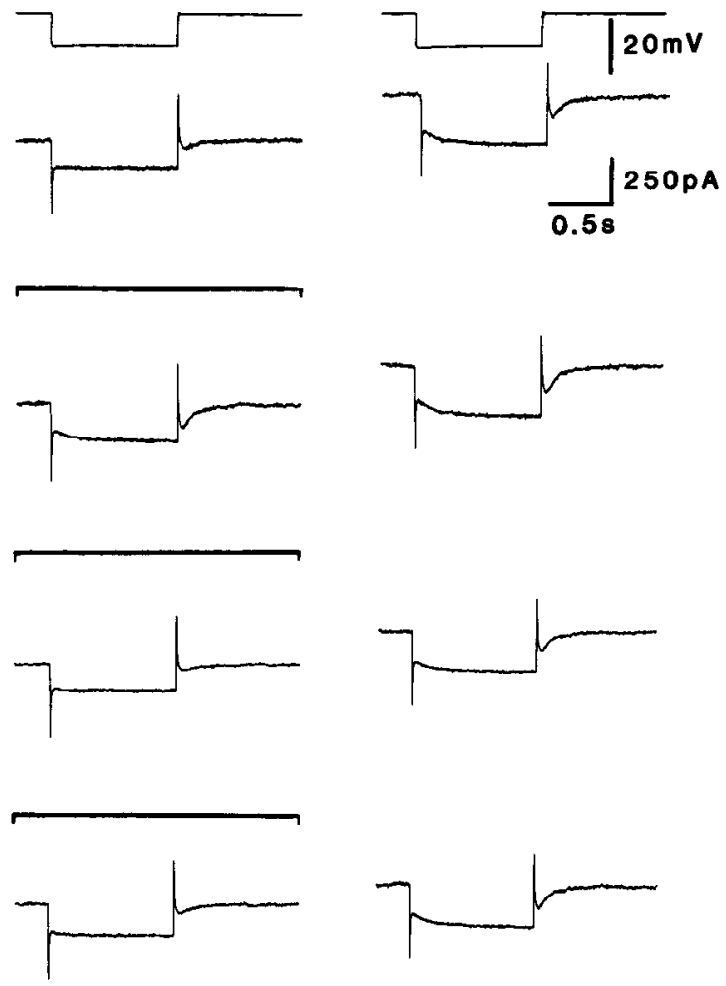

Figure 3. Comparison of the action of gallamine and pirenzepine $(P Z)$ on the cholinergic blockade of the M-current. Top trace, The cell is held in voltage clamp at a potential of $-40 \mathrm{mV}$ and stepped to $-54 \mathrm{mV}$ for $1 \mathrm{sec}$. This step results in a time-dependent inward relaxation of membrane current due to the closurc of M-current channels. Carbachol $(20 \mu \mathrm{M})$ applied during the time indicated by the bar blocks the inward relaxation. Gallamine applied for the 15 min preceding carbachol antagonizes blockade of the M-current induced by carbachol. After washing gallamine (30 $\mathrm{min}$ ), the carbachol-induced blockade of the M-current recovers. PZ $(0.3$ $\mu \mathrm{M})$ applied for 15 min only partially antagonizes the carbachol-induced blockade of the M-current (bottom trace). Four traces, continuous recordings from the same cell; resting membrane potential, $-62 \mathrm{mV}$. Timc, voltage, and current calibrations in top trace also apply to others. TTX was added to the bath. pocampus, we performed experiments in rats pretreated with PTX. PTX is able to ADP-ribosylate and inactivate the alpha subunit of a G-protein known to interact with muscarinic receptors (Kurose et al., 1983; Murayama and Ui, 1983). Hippocampal slices were prepared from rats that had been injected
$3 \mathrm{~d}$ prior to slicing. The effectiveness of the PTX injection was checked by testing the effect of 5-HT or baclofen on pyramidal neurons, the hyperpolarizing effect of these drugs being blocked in rats pretreated by PTX (see Andrade et al., 1986). Conventional intracellular recordings performed in 5 rats demonstrated
A

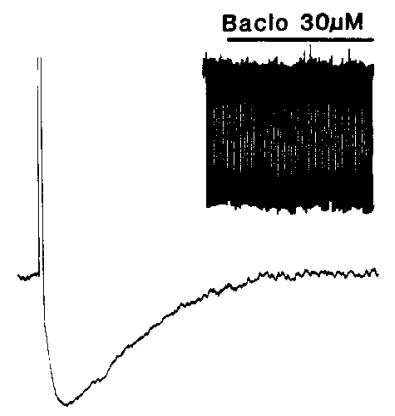

B

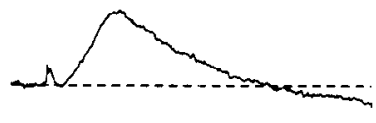

\section{CARB $1 \mu \mathrm{M}$}
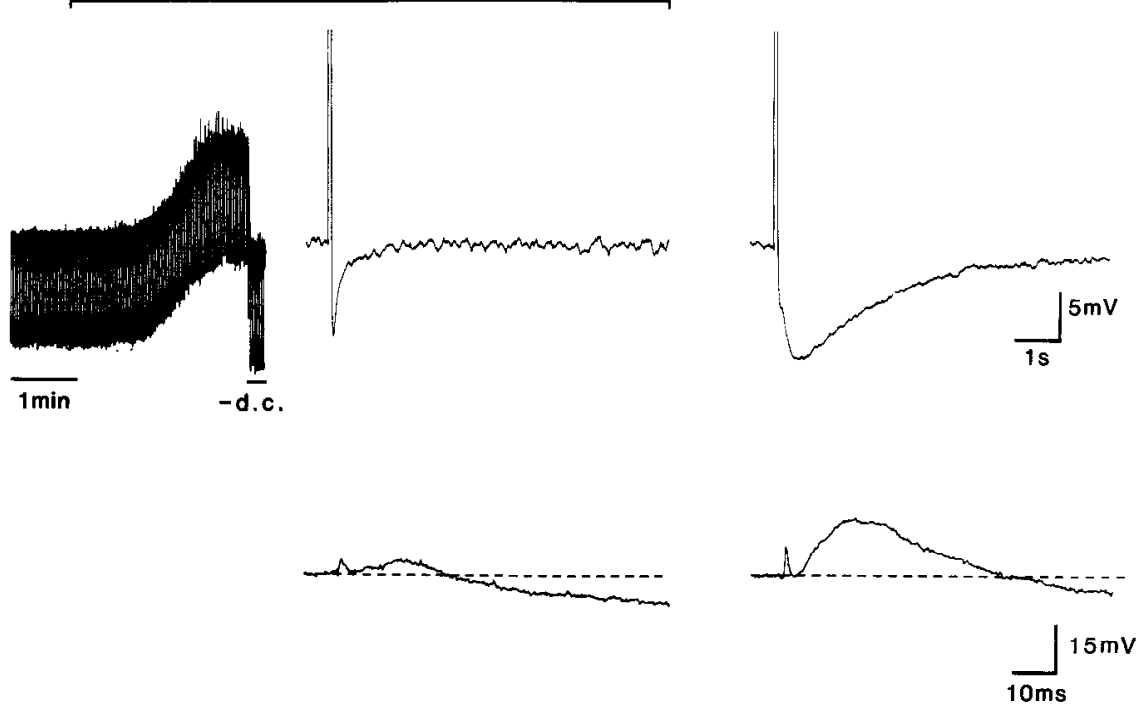

Figure 4. Cholinergic effects are preser ved in rats pretreated with pertussis toxin. In rats treated $3 \mathrm{~d}$ prior to the experiment by intracerebroventricular injection of pertussis toxin $(1.5 \mu \mathrm{g})$, carbachol still induces the effects described in Figure $1:$ in $A$, depolarization of the membrane associated with an increase in input resistance, and blockade of the AHP; in $B$, depression of the EPSP induced by afferent stimulation. Note in insert in $A$ the lack of effect of baclofen (Baclo $30 \mu \mathrm{M}$ ) on the membrane polarization when applied in the bath, establishing the effectiveness of the pertussis toxin injection (see Andrade et al., 1986). Membrane potential, $-57 \mathrm{mV}$. 
A

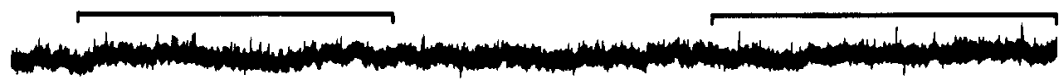

Figure 5. Carbachol is still able to suppress the M-current in rats pretreated with pertussis toxin. $A$, Application of serotonin $(5-H T 30 \mu \mathrm{M})$ or baclofen (Baclo $30 \mu \mathrm{M}$ ) during the time indicated by the bars does not produce the hyperpolarizations observed in normal rats. $B$, Same cell is recorded in voltage clamp and the M-current is elicited by hyperpolarizing steps $(-14 \mathrm{mV})$ from a holding potential of $-35 \mathrm{mV}$. Carbachol applied by superfusion blocks reversibly the M-current. Resting potential, $-57 \mathrm{mV}$. TTX was added to the bath.

that all the actions of carbachol were preserved. In cells in which 5-HT or baclofen clearly had no hyperpolarizing action, carbachol was able to depolarize the membrane $(n=10)$ and to block the AHP ( $n=8$ ) (Fig. 4). The depressant action on the

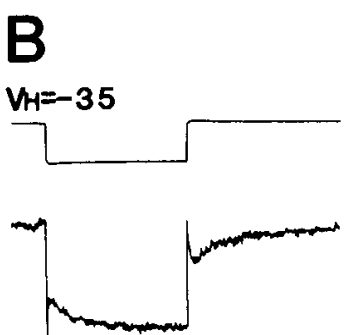

CARB $20 \mu \mathrm{M}$

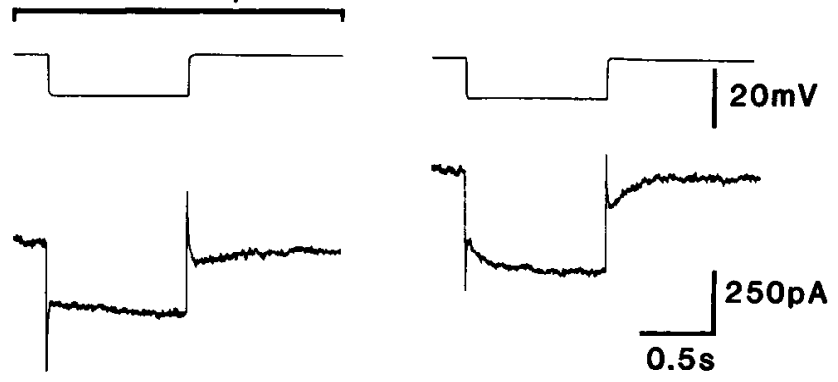

EPSP clearly occurred in 8 out of 12 cells (Fig. 4). However, in 5 cells that had particularly large IPSPs following the EPSP, possibly related to the PTX, this effect was not easy to check. Finally, voltage-clamp experiments in 7 rats indicated a clear

A

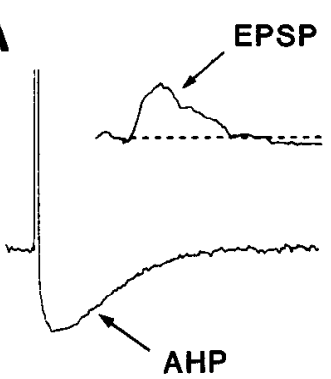

B

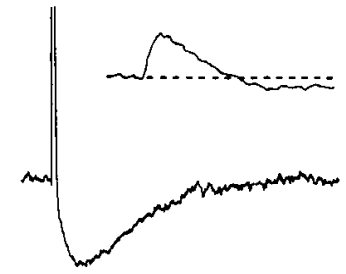

CARBACHOL $1 \mu \mathrm{M}$
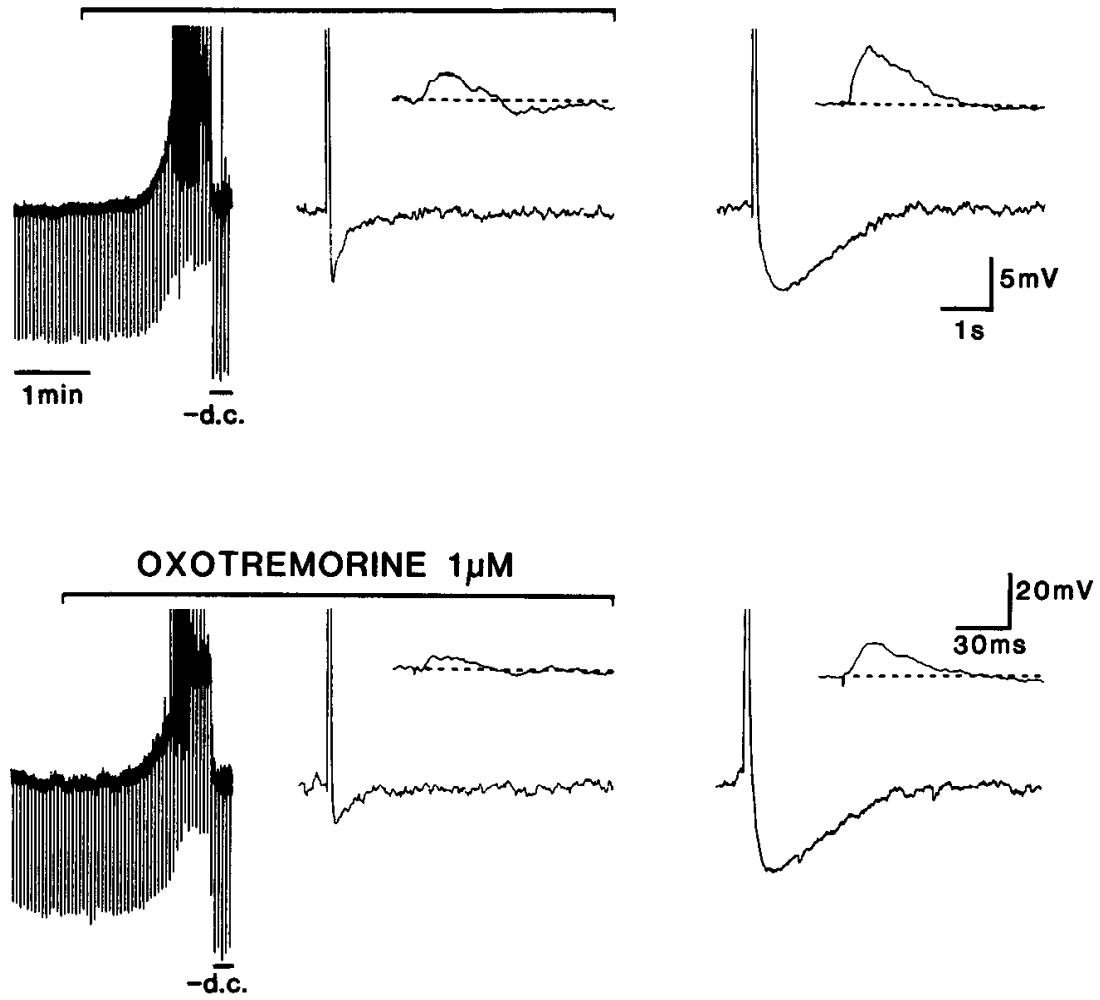

Figure 6. Carbachol and oxotremorine have similar efficacics for depolarizing the neuron, blocking the AHP, and depressing the EPSP. $A$, Chart recorder trace at left shows the AHP in response to a brief $(60 \mathrm{msec})$ depolarizing current pulse at a fast chart speed and, above this trace, the EPSP induced by stimulation of stratum radiatum. The chart speed was then reduced and constant-current hyperpolarizing pulses were applied at 0.3 $\mathrm{Hz}$. Carbachol $(\mathrm{Carb} 1 \mu \mathrm{M})$ applied by superfusion in the bath during the time indicated by the bar induces a strong depolarization associated with an increase in input resistance [as shown by repolarizing the membrane potential to the control value (-d.c.)], a blockade of the AHP, and a depression of the EPSP. These effects recover after washing carbachol from the bath. $B$, Oxotremorine $(1 \mu \mathrm{M})$ was applied to the same cell and produced very similar results. The calibrations for the pen records in $A$ apply to all pen records; the calibration for the EPSP in $B$ is the same for all EPSPs. Membrane potential, $-55 \mathrm{mV}$. 
A

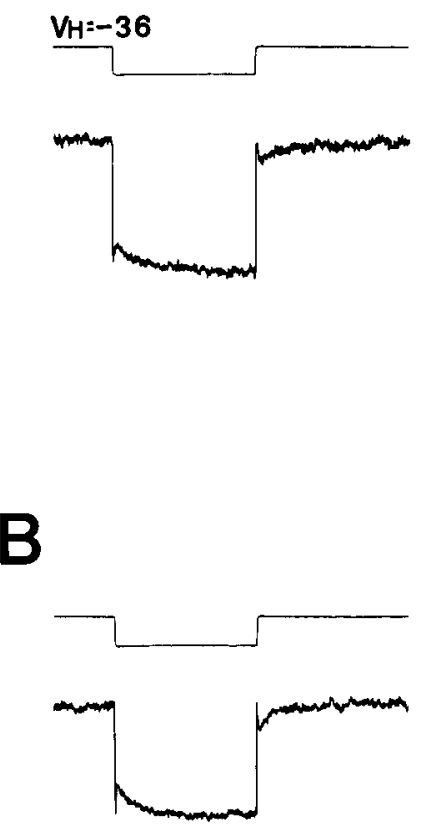

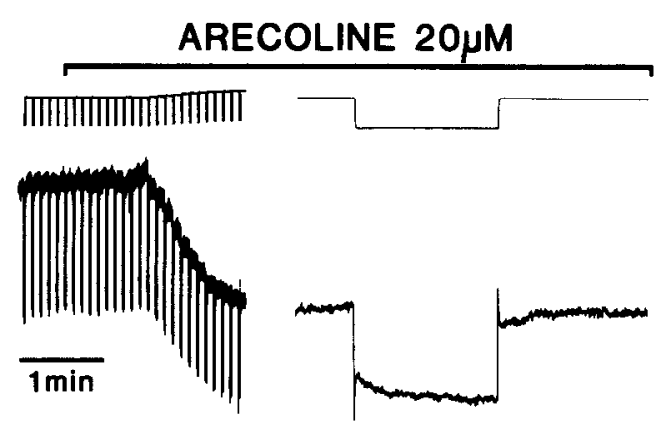
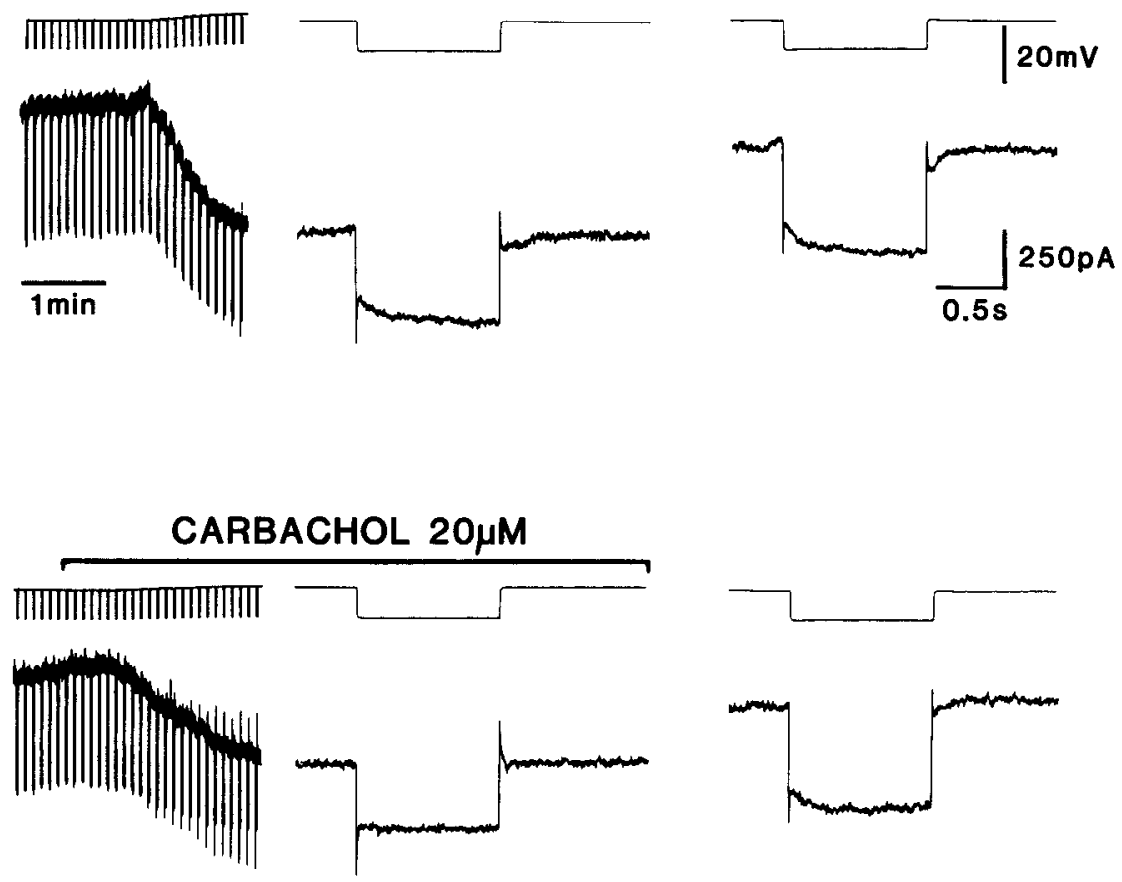

Figure 7. Differential effect of arecoline and carbachol on the M-current. $A$, The cell was held voltage-clamped at a potential of $-36 \mathrm{mV}$ and stepped to $-48 \mathrm{mV}$ for $1 \mathrm{sec}$ to elicit the M-current. The chart speed was then reduced and the M-current was elicited every 6 sec. Arecoline (20 $\mu \mathrm{M})$, a weak agonist for stimulating PI turnover, was applied by superfusion through the bath during the time indicated by the bar. Arecoline induced a large inward current and a decrease in instantaneous conductance but failed to suppress the M-current. After washing (20 min), carbachol is applied on the same cell in $B$ and induces an inward current and a decrease in instantaneous conductance and reversibly blocks the M-current. TTX was added to the bath. Calibrations in the top trace apply to the bottom trace. Resting membrane potential, $-63 \mathrm{mV}$,

suppression of the M-current by carbachol ( $n=11$; Fig. 5). These results make unlikely the involvement of a PTX-sensitive $\mathrm{G}$-protein in muscarinic effects in hippocampal neurons.

\section{Implication of phosphatidylinositol (PI) turnover}

Fisher et al. $(1983,1984)$ have classified the muscarinic agonists according to their ability to stimulate PI turnover. In their classification, oxotremorine-M (OXO-M) and carbachol are strong activators of PI turnover in various areas of the brain, including hippocampus. In contrast, arecoline, pilocarpine, and oxotremorine are only weak, partial agonists for stimulating this system. To check the possible involvement of PI turnover in the mediation of the muscarinic effects in the hippocampus, we tested the ability of these different agonists to evoke the 4 different cholinergic responses.

First, we found that the 2 categories of agonists produced a similar depolarization of the membrane potential, blockade of the AHP, and depression of the EPSP. This is shown in Figure 6 for carbachol and oxotremorine, which have markedly different potencies in stimulating PI turnover. Thus, the 2 classes of agonists cannot discriminate among these muscarinic responses.

In striking contrast, the M-current was strongly and reproducibly blocked by carbachol $(n=25)$ and OXO-M $(n=13)$ at 20 $\mu_{\mathrm{M}}$ but was little affected by the same concentration of the weak agonists pilocarpine $(n=8)$, arecoline $(n=5)$, and oxotremorine $(n=8)$ (see Table 2). Figures 7 and 8 present 2 examples of the action of a weak and a strong agonist applied on the same cell. Moreover, in agreement with biochemical results on PI turnover
(Fisher et al., 1983, 1984), oxotremorine, a weak agonist for stimulating PI turnover, could antagonize the effects of a strong agonist, OXO-M, in suppressing the M-current (Fig. 8). The differential effect of these cholinergic agonists, which closely parallels the biochemical results, clearly implicates the PI cycle in the cholinergic suppression of the M-current. We next examined which of the 2 main products resulting from PI turnover, diacylglycerol and inositol trisphosphate, might be involved in this effect.

\section{Is activation of protein kinase $C$ involved in the blockade of the $M$-current?}

The effect of phorbol esters, which directly activate protein kinase C (Castagna et al., 1982; Nishizuka, 1986), were examined on pyramidal neurons. In agreement with previous reports $(\mathrm{Ba}-$

Table 2. Effect of cholinergic agonists on the M-current

\begin{tabular}{|c|c|c|c|c|}
\hline \multirow[b]{2}{*}{ Agonist } & \multirow[b]{2}{*}{$n$} & \multicolumn{2}{|c|}{ M-current amplitude (pA) } & \multirow[b]{2}{*}{$\begin{array}{l}\text { Decrease } \\
(\%)\end{array}$} \\
\hline & & Control & $\begin{array}{l}\text { During } \\
\text { drug }\end{array}$ & \\
\hline Carbachol & 25 & $137 \pm 54$ & $7 \pm 20$ & $( \pm 12)$ \\
\hline Oxotremorine-M & 13 & $142 \pm 34$ & $4.7 \pm 9$ & $97( \pm 6)$ \\
\hline Oxotremorine & 8 & $125 \pm 26$ & $103 \pm 34$ & $18( \pm 17)$ \\
\hline Pilocarpine & 8 & $128 \pm 67$ & $117 \pm 70$ & $8.8( \pm 16)$ \\
\hline Arecoline & 5 & $207 \pm 106$ & $167 \pm 83$ & $19( \pm 12)$ \\
\hline
\end{tabular}

$n=$ number of neurons tested. Values are means \pm SD. All agonists were applied at $20 \mu \mathrm{M}$. 
A

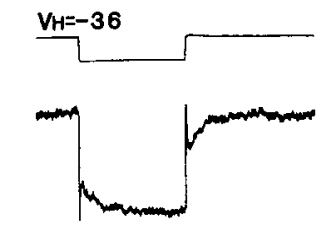

B

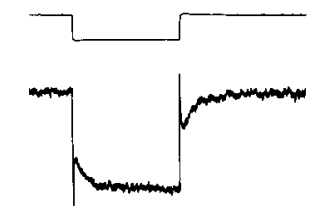

C

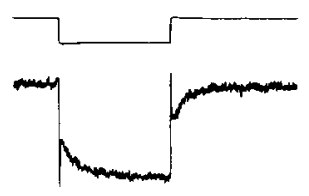

OXOTREMORINE $30 \mu \mathrm{M}$
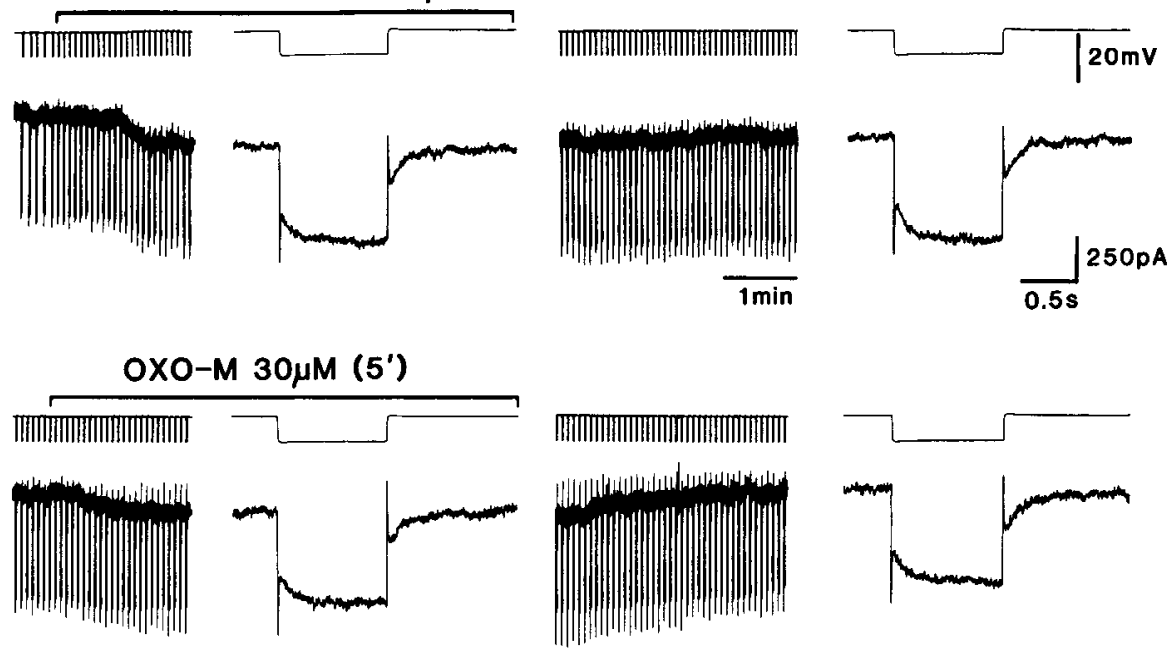

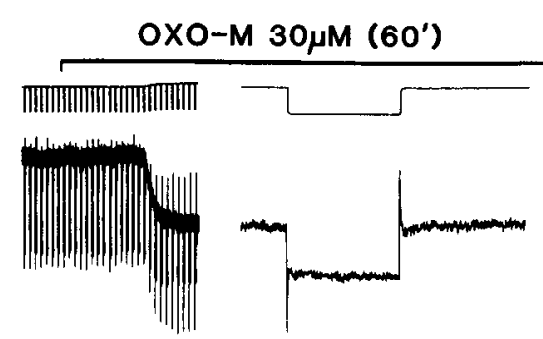

+OXOTREMORINE 30رM

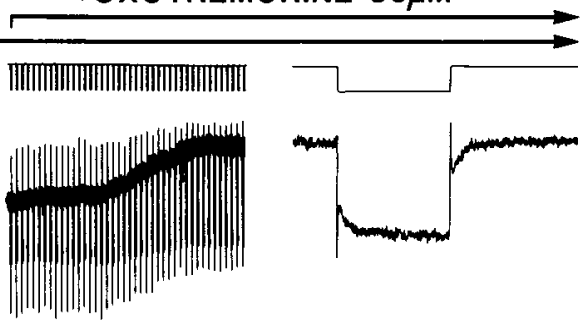

Figure 8. Oxotremorine antagonizes the effect of OXO-M on the M-current. In all records, the cell was held in voltage clamp at a potential of $-36 \mathrm{mV}$ and stepped to $-48 \mathrm{mV}$ to elicit the M-current. $A$, Oxotremorine $(30 \mu \mathrm{M})$, a weak agonist for stimulating PI turnover, applied by superfusion to the bath induced an inward current but failed to block the M-current. B, OXO-M (30 $\mu \mathrm{M})$, a full agonist for stimulating PI turnover, applied 5 min after stopping oxotremorine induced a small inward current but failed to block the M-current. $C$, Only after 60 min of washing out the oxotremorine did OXO-M strongly block the M-current. Oxotremorine added to the bath during the OXO-M application quickly reversed the depressing effect of OXO-M. Horizontal bars indicate the duration of application of the drugs. $A-C$ are continuous recordings from the same cell. Resting membrane potential, $-58 \mathrm{mV}$. Calibration in top trace applies to others. TTX was added to the bath.

raban et al., 1985; Malenka et al., 1986), activation of protein kinase $\mathrm{C}$ by phorbol esters mimicked the effect of carbachol in blocking the AHP (Fig. 9A2). In contrast, phorbol esters had no consistent effects on the suppression of the M-current $(n=9$; Fig. 9A1) and increased, rather than decreased, the EPSP. Moreover, after a long period of incubation of the slice in phorbol esters, application of OXO-M or carbachol still reversibly depressed the M-current (Fig. 9B2), although in 3 out of the 4 cells examined the blockade was incomplete. These results strongly suggest that protein kinase $C$ and DG do not serve as intracellular messengers for the muscarinic effect on depression of the M-current and EPSP. The blockade of the AHP by phorbol esters is not entirely consistent with the observation that weak agonists for PI stimulation are also able to block the AHP. This point will be discussed later.

\section{Possible involvement of $I_{3}$}

To evaluate the possibility of $\mathrm{IP}_{3}$ involvement in some of the cholinergic mechanisms described above, we performed experiments using a single-electrode voltage-clamp with electrodes filled with $\mathrm{IP}_{3}(20-60 \mathrm{mM}$ in $\mathrm{KCl})$. We examined for possible effects of $\mathrm{IP}_{3}$ over time as it diffused into the cell. During a 10 min period after penetrating a cell the M-current was progressively depressed [average depression, $74 \%( \pm 14) ; n=14$; Fig.
$10 A]$. In contrast, the Q-current, an anomalously rectifying current elicited by hyperpolarizing steps from hyperpolarized potentials $(-65$ to $-75 \mathrm{mV})$ was unchanged (Fig. 10B). The reduction in M-current, evoked by 12-15 $\mathrm{mV}$ hyperpolarizing pulses from a holding potential of -35 to $-45 \mathrm{mV}$, was associated with an inward shift in the holding current (average, 400 $\pm 76 \mathrm{pA} ; n=14)$ and a decrease in the instantaneous conductance $(21 \pm 14 \%$; Fig. 10). In contrast, it was always possible to record an AHP current. These data can be compared with the data obtained after application of carbachol or OXO-M, respectively: $95 \%( \pm 12)$ and $97 \%( \pm 6)$ of depression of the M-current (see Table 2), $486 \pm 56 \mathrm{pA}$ and $465 \pm 62 \mathrm{pA}$ of inward shift in the holding current, and $27 \%( \pm 20)$ and $26 \%$ $( \pm 16)$ of decrease in the instantaneous conductance.

Finally, we tested whether the effect of muscarinic agonists on the suppression of the M-current could be due to an indirect effect through mobilization of intracellular calcium secondary to the action of $\mathrm{IP}_{3}$. For this purpose, we buffered intracellular calcium by applying calcium chelators EGTA ( $200 \mathrm{~mm}$ in $3 \mathrm{M}$ $\mathrm{KCl} ; n=6$ ) or BAPTA ( $200 \mathrm{mM}$ in $3 \mathrm{M} \mathrm{KCl} ; n=3$ ) into the cells. These compounds were applied into the cells by diffusion from the recording electrodes. In these conditions, the AHP current was abolished 5 min after impalement, but carbachol and OXO-M were still able to fully suppress the M-current (Fig. 

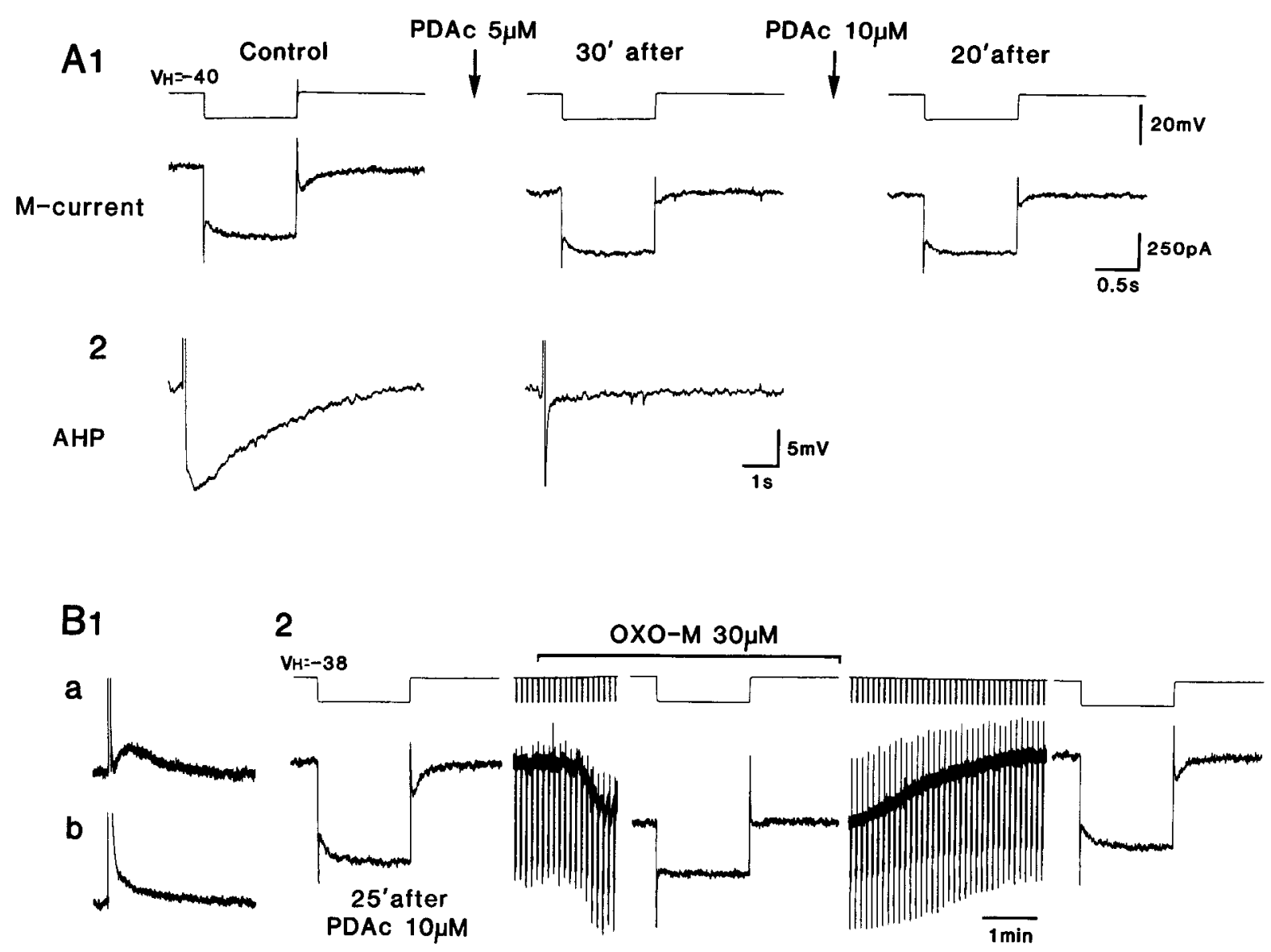

Figure 9. Phorbol esters do not block the M-current. $A$, The cell was held in voltage clamp $(A l)$ at a potential of $-40 \mathrm{mV}$ and stepped to -55 $\mathrm{mV}$ to elicit the M-current. TTX had been added to the bath. A2, The AHP from the same cell was recorded in current clamp. Phorbol 12,13diacetate $(P D A c), 5 \mu \mathrm{M}$, was applied continuously by superfusion through the bath (arrow). Thirty minutes after the beginning of the superfusion, it was still possible to elicit the M-current from the same holding potential $(-40 \mathrm{mV})$. In contrast, the slow AHP had been abolished. Increasing the concentration of PDAc $(10 \mu \mathrm{M})$ did not suppress the M-current recorded 20 min after the beginning of the perfusion. Resting membrane potential, $-55 \mathrm{mV}$. $B$, Another cell recorded in voltage clamp was superfused with phorbol 12,13-diacetate, $10 \mu \mathrm{M}$. Twenty minutes after the beginning of the superfusion, the AHP current was abolished $(B 1 b)$. The M-current was then elicited (B2) by a 1 sec $13 \mathrm{mV}$ hyperpolarizing pulse from a holding potential of $-38 \mathrm{mV}$. The M-current was still present, and it was possible to reversibly suppress it by application of OXO-M. The duration of the application is indicated by the bar. Resting membrane potential, $-68 \mathrm{mV}$. Time, voltage, and current calibrations in $A 1$ apply to $B 2$; the time calibration in $A 2$ applies to $B 1$, and the current calibration in $A 1$ applies to $B 1$.

11). These results suggested that a rise in intracellular calcium might not be necessary for the muscarinic blockade of the M-current.

In summary, cholinergic responses can be differentiated into at least 2 effects in terms of PI turnover: (1) the AHP, which is blocked by activation of protein kinase $\mathrm{C}$; and (2) the M-current, which is depressed by increasing the intracellular concentration of $\mathrm{IP}_{3}$. [The first result is not entirely in accord with results concerning the 2 classes of cholinergic agonists (see Discussion).]

\section{Discussion}

Classification of $M_{1}-M_{2}$

Our results show that gallamine is able to discriminate between the different cholinergic responses. Gallamine is able to produce an almost total antagonism of the blockade of the M-current and of the depression of the EPSP. In contrast, this antagonist, specific for $\mathbf{M}_{2}$ receptors, had little effect on the membrane depolarization and the blockade of the AHP by cholinergic agonists. On the other hand, we were unable to clearly differentiate among any of the cholinergic responses with pirenzepine, an $\mathrm{M}_{1}$ antagonist. These results differ to some extent from those of Muller and Misgeld (1986), who found that pirenzepine blocked the cholinergic depolarization but not the AHPs. They also differ from the results on olfactory cortex neurons of Constanti and Sim (1987b), who reported that gallamine prevents the muscarinic blockade of the AHP. However, our results showing that gallamine antagonizes the cholinergic blockade of the M-current are in accord with those of Constanti and Sim (1987a). From our results we conclude that the depolarization and the blockade of the AHPs by low concentrations of carbachol are likely to be mediated by $M_{1}$ receptors, while the blockade of the M-current and presynaptic inhibition of EPSPs are likely to be mediated by $\mathrm{M}_{2}$ receptors. The $\mathrm{M}_{2}$ naturc for the presynaptic muscarinic receptors has been demonstrated in other systems. For example, the muscarinic receptors located on cholinergic terminals in the cerebral cortex appear to be of the $\mathbf{M}_{2}$ type: Indeed, the release of $\mathrm{ACh}$ from cholinergic terminals is modulated by $\mathrm{M}_{2}$, but not by $\mathbf{M}_{1}$, agonists and antagonists (Meyer and Otero, 1985). Furthermore, there is a decrease in $\mathrm{M}_{2}$ receptor numbers in cerebral cortex following destruction of the cholinergic afferent pathway (Mash et al., 1985). 
A

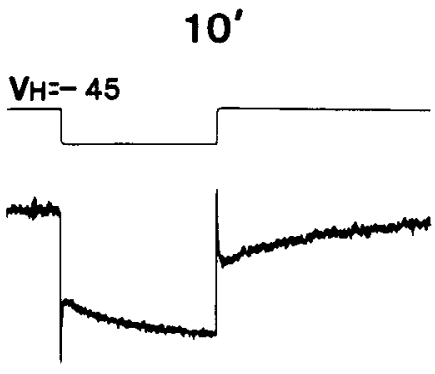

Figure 10. Effect of intracellular application of inositol trisphosphate $\left(\mathbf{I P}_{3}\right)$ in CA1 pyramidal cells. The cell was recorded in voltage clamp $10 \mathrm{~min}$ (left column) and 60 min (right column) after impalement with an electrode filled with $3 \mathrm{~m} \mathrm{KCl}$ plus $60 \mathrm{~mm} \mathrm{IP}_{3}$. $A$, The M-current was elicited by applying a 1 sec hyperpolarizing step of $12 \mathrm{mV}$ from a holding potential of $-45 \mathrm{mV}$. The M-current was strongly depressed 60 min after the beginning of the diffusion of $\mathrm{IP}_{3}$ into the cell. $B$, The Q-current evoked from the same cell by a $22 \mathrm{mV}$ hyperpolarizing pulse from a holding potential of $-70 \mathrm{mV}$ was unchanged. Resting membrane potential, $-57 \mathrm{mV}$. The calibration in $A$ also applies to $B$.
B

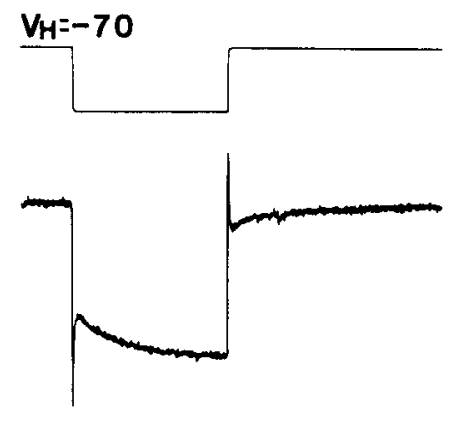

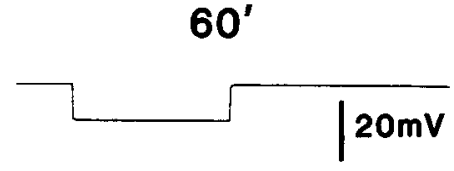

Im
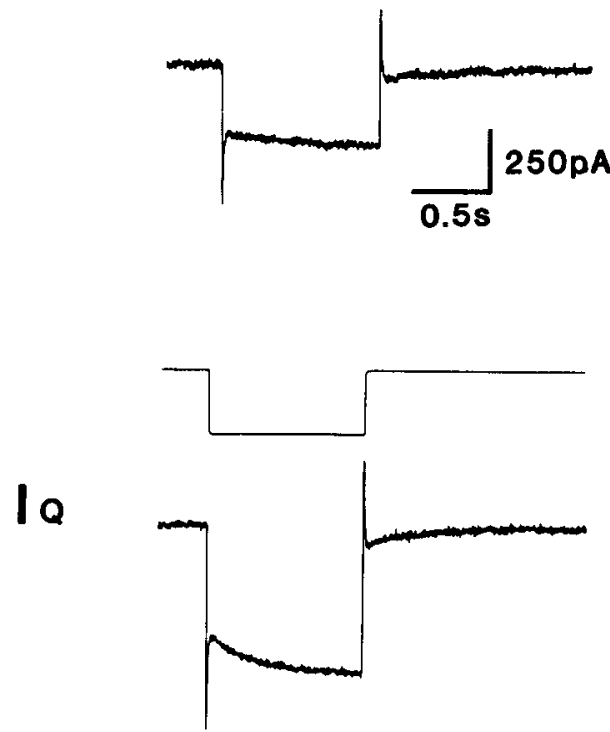

Classification in terms of coupling with a biochemical effector system

Involvement of a $G$-protein

G-proteins have been shown to be involved in coupling muscarinic receptors to $\mathrm{K}^{+}$channels in the heart (Breitwieser and Szabo, 1985; Pfaffinger et al., 1985) and to phospholipase in Xenopus oocytes (Dascal et al., 1986). In addition, G-proteins are known to couple receptors to ion channels in hippocampal pyramidal cells (Andrade et al., 1986). However, the muscarinic effects in hippocampus do not appear to involve a PTX-sensitive G-protein. Our experiments clearly show that in rats pretreated with PTX in which GABA $\mathrm{B}_{\mathrm{B}}$ and 5-HT responses are completely blocked, the muscarinic responses persist; it is still possible to induce membrane depolarization, depression of the EPSP, and blockade of the AHP and of the M-current. Thus, it is unlikely that a PTX-sensitive G-protein $\left(G_{i}\right.$ or $\left.G_{o}\right)$ is required for any of the muscarinic responses, but it is still possible that other GTP regulatory proteins, as yet unidentified and insensitive to PTX, are involved, as already suggested in cardiac cells (BrownMasters et al., 1985).

\section{Stimulation of PI turnover}

Muscarinic agonists have long been known to stimulate PI turnover in the brain, but only recently has the differential potency of these agonists been demonstrated in the brain (Fisher et al., 1983, 1984; Brown et al., 1984; Jacobson et al., 1985). Agonists known to be fully effective for stimulating PI turnover strongly block $I_{M}$ (oxotremorine-M, carbachol). On the other hand, poor agonists for stimulating PI turnover (arecoline, pilocarpine, and

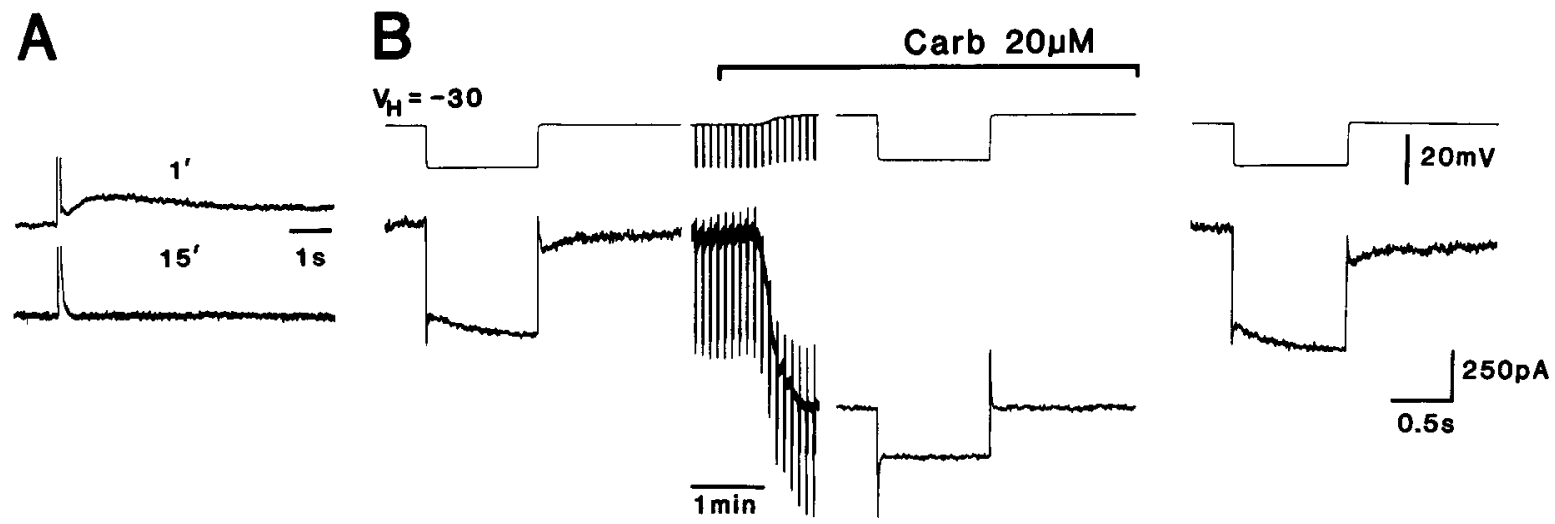

Figure 11. Buffering intracellular $\mathrm{Ca}^{2+}$ failed to block the action of carbachol. The cell was recorded with an electrode filled with $3 \mathrm{M} \mathrm{KCl}$ plus $200 \mathrm{~mm}$ BAPTA, a calcium chelator. $A$, At 1 min after penetrating the cell, an AHP-current was recorded, but this was entirely blocked within 15 $\min . B$, The M-current was then evoked by $17 \mathrm{mV}$ hyperpolarizing steps from a holding potential of $-30 \mathrm{mV}$. Carbachol (carb), applied during the time indicated by the bar, blocked the M-current. TTX was added to the bath. Resting membrane potential, $-58 \mathrm{mV}$. 
oxotremorine) are unable to depress $I_{M}$. These results suggest a role for PI turnover in the muscarinic suppression of the M-current. The lack of effect of weak agonists on the blockade of $I_{M}$ has previously been described in bullfrog sympathetic neurons (Adams et al., 1982) and in olfactory cortical neurons (Constanti and Sim, 1987b), but no correlation had been shown with the PI system. In contrast to the results obtained on $I_{M}$, cholinergic agonists did not discriminate between the depolarizing responses, blockade of the AHP, or depression of the EPSP. The fact that the weak agonists for stimulating PI turnover depolarize the membrane and block the AHP to the same extent as the strong agonists (even at low concentrations) could be explained in 2 ways. One possible interpretation is that relatively low levels of DG generated by muscarinic receptor activation are sufficient to activate enough PKC to block the slow AIIP, while relatively larger amounts of $\mathrm{IP}_{3}$, also generated by PI turnover, block the M-current. Alternatively, it is possible that the blockade of the slow AHP by ACh is not mediated by PI turnover but by some other intracellular messenger and that only the M-current blockade is mediated by PI turnover.

The finding that agonists such as oxotremorine, pilocarpine, or arecoline, which have no effect on $I_{M}$, had nearly the same potency in depolarizing pyramidal neurons as carbachol or OXO-M, which blocked $I_{M}$, indicates that the slow cholinergic depolarization of these neurons is not linked principally to the blockade of $I_{M}$ (see Madison et al., 1987).

Our pharmacological studies suggest that the suppression of the M-current is linked to the activation of PI turnover. We have found, in agreement with a previous report (Malenka et al., 1986), that phorbol esters and the subsequent activation of protein kinase $\mathrm{C}$ have no consistent effect on the $\mathrm{M}$-current. In contrast, $\mathrm{IP}_{3}$ was able to reduce this current. These results raise the possibility that the muscarinic blockade of $I_{M}$ is mediated by an increase in the intracellular concentration of $\mathrm{IP}_{3}$ or one of its metabolites, subsequent to the stimulation of PI turnover. Different conclusions have been reached in frog sympathetic ganglion cells (Brown and Adams, 1987; Pfaffinger et al., 1988) and the neuroblastoma-glioma hybrid cell line (Brown and Higashida, 1988), in which phorbol esters have been found to reduce $I_{M}$ by $50 \%$ and $I P_{3}$ appears to have little effect on $I_{M}$. This raises the possibility that different mechanisms may be involved in blocking $I_{M}$ in different cell types.

Biochemical data have suggested that $\mathrm{IP}_{3}$ is a potential second messenger (Berridge, 1984). One of its principal actions is to release calcium from intracellular stores (Berridge and Irvine, 1984), but $\mathrm{IP}_{3}$ may also have other cellular functions by itself (Swilem et al., 1986) or through its metabolites, including the dephosphorylated derivatives $\mathrm{IP}_{2}$ and $\mathrm{IP}_{1}$ or the phosphorylated derivative $\mathrm{IP}_{4}$ (Irvine and Moor, 1986; Houslay, 1987).

The effect of $\mathrm{IP}_{3}$ as an inducer of Ca-release has been demonstrated in various non-neuronal cell types (reviewed by $\mathrm{Ab}$ del-Latif, 1986). Our results show that the suppression of the $M$-current by muscarinic agonists occurs even in neurons where intracellular calcium has been chelated (using BAPTA- or EGTAfilled electrodes). This suggests that the blockade of the M-current by muscarinic agonists may not require a rise in intracellular calcium. However, for technical reasons it has not been possible to study the effect of calcium chelators directly on the action of $\mathrm{IP}_{3}$. These experiments could be realized only in preparations allowing the placement of 2 electrodes in the same cell.

It is possible that $\mathrm{IP}_{3}$ could act directly on potassium channels in inducing their closure. Recent results have led to the conclu- sion that some actions of $\mathrm{IP}_{3}$ do not involve the mobilization of calcium (Kuno and Gardner, 1987). It has been found in adrenal chromaffin cells that the release of $\mathrm{IP}_{3}$ induced by muscarinic agonist stimulation occurred without modification of the intracellular calcium level (Swilem et al., 1986).

Numerous biochemical studies have attempted to relate muscarinic subtypes to specific second-messenger systems, but no clear consensus has emerged. For instance, some reports have proposed that $M_{2}$ receptors may act principally by inhibiting adenylate cyclase, whereas $\mathbf{M}_{1}$ receptors would be linked to PI turnover (Watson et al., 1984; Gil and Wolfe, 1985). However, other investigations suggest that both types of muscarinic receptors are involved in PI stimulation (Lazareno et al., 1985; Fisher and Agranoff, 1987). The results presented in this paper do not present an evident correlation between receptor subtypes and second-messenger systems.

\section{References}

Abdel-Latif, A. A. (1986) Calcium mobilizing receptors, polyphosphoinositides, and the generation of second messengers. Pharmacol. Rev. 38: 227-272.

Adams, P. R., D. A. Brown, and A. Constanti (1982) Pharmacological inhibition of the M-current. J. Physiol. (Lond.) 332: 223-262.

Andrade, R., R. C. Malenka, and R. A. Nicoll (1986) A G-protein couples serotonin and $\mathrm{GABA}_{B}$ receptors to the same channel in hippocampus. Science 234: 1261-1265.

Baraban, J. M., S. H. Snyder, and B. E. Alger (1985) Protein kinase $\mathrm{C}$ regulates ionic conductance in hippocampal pyramidal neurons: Electrophysiological effects of phorbol esters. Proc. Natl. Acad. Sci. USA 82: 2538-2542.

Benardo, L. S., and D. A. Prince (1982) Ionic mechanisms of cholinergic excitation in mammalian hippocampal pyramidal cells. Brain Res. 249: 333-344.

Berridge, M. J. (1984) Inositol trisphosphate and diacylglycerol as second messengers. Biochem. J. 220: 345-360.

Bcrridge, M. J., and R. F. Irvine (1984) Inositol trisphosphate, a novel second messenger in cellular signal transduction. Nature 312: 315321

Bonner, T. I., N. J. Buckley, A. L. Young, and M. R. Braun (1987) Identification of a family of muscarinic acetylcholine receptor genes. Science 237: 527-532.

Breitwieser, G. E., and G. Szabo (1985) Uncoupling of cardiac muscarinic and $\beta$-adrenergic receptors from ion channels by a guanine nucleotide analogue. Nature 317: 538-540.

Brown, D. A., and P. R. Adams (1980) Muscarinic suppression of a novel voltage-sensitive $\mathrm{K}^{+}$current in a vertebrate neurone. Nature 183: 673-676.

Brown, D. A., and P. R. Adams (1987) Effects of phorbol dibutyrate on M-currents and M-current inhibition in bullfrog sympathetic neurons. Cell. Molec. Neurobiol. 7: 255-269.

Brown, D. A., and H. Higashida (1988) Inositol 1,4,5-trisphosphate and diacylglycerol mimic bradykinin effects on mouse neuroblastoma $x$ rat glioma hybrid cells. J. Physiol. (Lond.) 397: 185-207.

Brown, E., D. A. Kendall, and S. R. Nahorski (1984) Inositol phospholipid hydrolysis in rat cerebral cortical slices: I. Receptor characterization. J. Neurochem. 42: 1379-1387.

Brown-Masters, S., M. W. Martin, T. K. Harden, and J. H. Brown (1985) Pertussis toxin does not inhibit muscarinic receptor-mediated phosphoinositide hydrolysis or calcium mobilization. Biochem. J. 227: 933-937.

Burke, R. E. (1986) Gallamine binding to muscarinic $M_{1}$ and $M_{2}$ receptors, studied by inhibition of $\left[{ }^{3} \mathrm{H}\right]$ pirenzepine and $\left[{ }^{3} \mathrm{H}\right]$ quinuclidinylbenzilate binding to rat brain membranes. Mol. Pharmacol. 30: 58-68.

Castagna, M., Y. Takai, K. Kaibuchi, K. Sano, U. Kikkawa, and Y. Nishizuka (1982) Direct activation of $\mathrm{Ca}^{2+}$-activated, phospholipid-dependent protein kinase by tumor-promoting phorbol esters. J. Biol. Chem. 257: 7847-7851

Cole, A. E., and R. A. Nicoll (1984) The pharmacology of cholinergic excitatory responses in hippocampal pyramidal cells. Brain Res. 305: 283-290. 
Constanti, A., and J. A. Sim (1987a) Muscarinic receptors mediating suppression of the M-current in guinea-pig olfactory cortex neurones may be of the $\mathrm{M}_{2}$-subtype. Br. J. Pharmacol. 90: 3-5.

Constanti, A., and J. A. Sim (1987b) Calcium-dependent potassium conductance in guinea-pig olfactory cortex neurones in vitro. J. Physiol. (Lond.) 387: 173-194.

Dascal, N., C. Ifune, R. Hopkins, T. P. Snutch, H. Lübbert, N. Davidson, M. I. Simon, and H. A. Lester (1986) Involvement of a GTP binding protein in mediation of serotonin and acetylcholine responses in Xenopus oocytes injected with rat brain messenger RNA. Molcc. Brain Res. 1: 201-209.

Egan, T. M., and R. A. North (1985) Acetylcholine acts on a $\mathbf{M}_{2}$ muscarinic receptor to excite rat locus coeruleus neurons. Br. J. Pharmacol. 85: 733-735.

Egan, T. M., and R. A. North (1986) Acetylcholine hyperpolarizes central neurons by acting on an $\mathbf{M}_{2}$ muscarinic receptor. Nature 319 : 405-407.

Eglen, R. M., and R. L. Whiting (1986) Muscarinic receptor subtypes: A critique of the current classification and a proposal for a working nomenclature. J. Auton. Pharmacol. 5: 323-346.

Fisher, S. K., and B. W. Agranoff (1987) Receptor activation and inositol lipid hydrolysis in neural tissues. J. Neurochem. 48: 9991017.

Fisher, S. K., P. D. Klinger, and B. W. Agranoff (1983) Muscarinic agonist binding and phospholipid turnover in brain. J. Biol. Chem. 258: 7358-7363.

Fisher, S. K., J. C. Figueiredo, and R. T. Bartus (1984) Differential stimulation of inositol phospholipid turnover in brain by analogs of oxotremorine. J. Neurochem. 43: 1171-1179.

Gil, D. W., and B. B. Wolfe (1985) Pirenzepine distinguishes between muscarinic receptor-mediated phosphoinositide breakdown and inhibition of adenylate cyclase. J. Pharmacol. Exp. Ther. 232: 608-616.

Halliwell, J. V., and P. R. Adams (1982) Voltage-clamp analysis of muscarinic excitation in hippocampal neurons. Brain Res. 250: 7192.

Hammer, R., C. P. Berrie, N. J. M. Birdsall, A. S. V. Burgen, and E. C. Hulme (1980) Pirenzepine distinguishes between different subclasses of muscarinic receptors. Nature 283: 90-92.

Higashida, H., and D. A. Brown (1986) Two polyphosphatidylinositide metabolites control two $\mathrm{K}^{+}$currents in a neuronal cell. Nature 323: 333-335.

Hounsgaard, J. (1978) Presynaptic inhibitory action of acetylcholine in area $\mathrm{CA}_{\text {, }}$ of the hippocampus. Exp. Neurol. 62: 787-797.

Houslay, M. D. (1987) Egg activation unscrambles a potential role for $\mathrm{IP}_{4}$. Trends Biochem. Sci. 12: 1-2.

Irvine, R. F., and R. M. Moor (1986) Micro-injection of inositol 1,3,4,5-tetrakisphosphate activates sea urchin eggs by a mechanism dependent on external $\mathrm{Ca}^{2+}$. Biochem. J. 240: 917-920.

Jacobson, M. D., M. Wusteman, and C. P. Downes (1985) Muscarinic receptors and hydrolysis of inositol phospholipids in rat cerebral cortex and parotid gland. J. Neurochem. 44: 465-472.

Kuno, M., and P. Gardner (1987) Ion channels activated by inositol 1,4,5-trisphosphate in plasma membrane of human T-lymphocytes. Nature 326: 301-304.
Kurose, H., T. Katada, T. Amano, and M. Ui (1983) Specific uncoupling by islet-activating protein, pertussis toxin, of negative signal transduction via $\alpha$-adrenergic, cholinergic, and opiate receptors in neuroblastoma $\times$ glioma hybrid cells. J. Biol. Chem. 258: 4870-4875.

Lazareno, S., D. A. Kendall, and S. R. Nahorski (1985) Pirenzepine indicates heterogeneity of muscarinic receptors linked to cerebral inositol phospholipid metabolism. Neuropharmacology 24: 593-595.

Madison, D. V., B. Lancaster, and R. A. Nicoll (1987) Voltage clamp analysis of cholinergic action in the hippocampus. J. Neurosci. 7: 733-741.

Malenka, R. C., D. V. Madison, R. Andrade, and R. A. Nicoll (1986) Phorbol esters mimic some cholinergic actions in hippocampal pyramidal neurons. J. Neurosci. $6: 475-480$.

Mash, D. C., D. D. Flynn, and L. T. Potter (1985) Loss of $\mathbf{M}_{2}$ muscarine receptors in the cerebral cortex in Alzheimer's disease and experimental cholinergic denervation. Science 228: 1115-1117.

McCormick, D. A., and D. A. Prince (1985) Two types of muscarinic response to acetylcholine in mammalian cortical neurons. Proc. Natl. Acad. Sci. USA 82: 6344-6348.

McCormick, D. A., and D. A. Prince (1986) Acetylcholine induces burst firing in thalamic reticular neurons by activating a potassium conductance. Nature 319: 402-405.

Meyer, E. M., and D. H. Otero (1985) Pharmacological and ionic charactcrizations of the muscarinic receptors modulating $\left[{ }^{3} \mathrm{H}\right]$ acetylcholine release from rat cortical synaptosomes. J. Neurosci. 5: 12021207.

Muller, W., and U. Misgeld (1986) Slow cholinergic excitation of guinea pig hippocampal neurons is mediated by two muscarinic receptor subtypes. Neurosci. Lett. 67: 107-112.

Murayama, T., and M. Ui (1983) Loss of the inhibitory function of the guanine nucleotide regulatory component of adenylate cyclase due to its ADP ribosylation by islet-activating protein, pertussis toxin, in adipocyte membranes. J. Biol. Chem. 258: 3319-3326.

Nicoll, R. A., and B. E. Alger (1981) A simple chamber for recording from submerged brain slices. J. Neurosci. Methods 4: 153-156.

Nishizuka, Y. (1986) Studies and perspective of protein kinase C. Science 233: 305-312.

Pfaffinger, P. J., J. M. Martin, D. D. Hunter, N. M. Nathanson, and B. Hille (1985) GTP-binding proteins couple cardiac muscarinic receptors to a K channel. Nature 317: 536-538.

Pfaffinger, P. J., M. D. Leibowitz, M. M. Bosma, W. Almers, and B. Hille (1988) M-current suppression by agonists: the role of the phospholipase $C$ pathway. Biophys. J. 53: 637a.

Potter, L. T., D. D. Flynn, H. E. Hanchett, D. L. Kalinoski, J. LuberNarod, and D. C. Mash (1984) Independent $M_{1}$ and $M_{2}$ receptors: Ligands, autoradiography and functions. Trends Pharmacol. Sci. Suppl. 22-31.

Swilem, A. F., H. Yagisawa, and J. N. Hawthorne (1986) Muscarinic release of inositol trisphosphate without mobilization of calcium in bovine adrenal chromaffin cells. J. Physiol. (Lond.) 81: 246-251.

Watson, M., T. W. Vickroy, W. R. Roeske, and H. I. Yamamura (1984) Subclassification of muscarinic receptors based upon the selective antagonist pirenzepine. Trends Pharmacol. Sci. Suppl. 9-11. 